\title{
Cultivating Senior Application-Oriented Technology Talents Based on Universities-Enterprises Community of Interests
}

\author{
Shiping $\mathrm{Ye}^{1, \mathrm{a}}$, Jinbiao Jin ${ }^{2, \mathrm{~b}}$ and Xiaomi Du ${ }^{3, \mathrm{c}}$ \\ ${ }^{1} 8$, Shuren Road, Zhejiang Shuren University, Hangzhou, Zhejiang, 310015, China \\ 2 8, Shuren Road, Zhejiang Shuren University, Hangzhou, Zhejiang, 310015, China \\ ${ }^{3}$ 8, Shuren Road, Zhejiang Shuren University, Hangzhou, Zhejiang, 310015, China \\ a email:149466712@qq.com, ${ }^{b}$ email:1113994458@qq.com, ${ }^{c}$ email:duxm501@163.com
}

Keywords: talents training, senior application-oriented technology talents, universities-enterprises cooperation, community of interests

\begin{abstract}
Training senior application-oriented technology talents has been an important mission for application technologies-oriented universities, and universities-enterprises cooperation is a critical way for collaborative training of technology talents training to satisfy social demands. This article analyzed problems existed and influencial factors of current application-oriented technology talents training in universities, and then proposed an important carrier for senior application-oriented technology talents training that universities and enterprises formed as a community of interests. We have introduced the main connotation, organizational forms, operating mechanism and predominant effects of the community of interests. Furthermore, we have discussed important roles of the community of interests in specialty offering and connotation construction, talents training mode reform and innovation capacity and entrepreneurship of college students and other key links of senior application-oriented technology talents training, with a successful practice in Zhejiang Shuren University.
\end{abstract}

\section{Introduction}

As industry 4.0 approaches, the digital and intelligent technologies are profoundly changing the production mode and industrial form of manufacturing sectors and enterprises' demands for personnel, and there will be increasing urgent needs for senior application-oriented technology talents who grasp skills of information technology and related fields. According to a report from McKinsey Global Institute, high-tech enterprises in the world will face a shortfall of about 40 million technology talents by 2020 , especially the manufacturing industry. As the largest manufacturing power in the world, China is in a period of economic restructuring and industrial upgrading currently, and needs a large number of high-quality senior application-oriented technology talents urgently. Consultants from McKinsey pointed out that China is likely to become the worst hit by the shortfall of technology talents. By 2020, the shortfall of technology talents in China will reach about 22 million. Facing the severe shortage of senior application-oriented technology talents, some Chinese universities are required to be transformed to application-oriented universities and to deepen production-education integration and universities-enterprises cooperation, to train high-quality workers and technologies-oriented talents".

Universities-enterprises cooperation is a critical way for senior application-oriented technology talents training. Numerous scholars worldwide have paid a lot of efforts from various perspectives. For instance, Adinarayana Kalanidhi[1], Xinmin Chen [2] and Hongtian Zhang [3] have made research and practice on the theories of universities-enterprises cooperation and practice in colleges and universities. We and teachers from Zhejiang Shuren University have made meaningful efforts in fully mobilizing the enthusiasm of enterprises, effective mining the junctions of schools and enterprises' appeal for interests and training senior technology talents through universities-enterprises collaboration by centering on the goal of constructing a "teaching service-oriented university"[4], closely relying on regional industry economy and through building universities-enterprises community of interests. 


\section{Key problems existing in application-oriented technology talents training}

1)The incompleteness of application-oriented technology talents training system. Limited by the old operating mechanism, the teaching in universities is still dominated by theoretical knowledge, with insufficient time for practice teaching. The teaching content is less systematic and lack of continuity, systematization, coordination, specialized practice teaching scheduling, and the mechanisms for research, management and evaluation, and there is no relatively complete available system of practice teaching.

2)Superficiality of application-oriented technology talents training process. Deeply influenced by traditional thoughts, many students mistake "practical capacity training" as equal to "manual labor", and regard them as a behavior unbefitting "undergraduate", so they have some kind of resistance to the practical training in enterprises. Hence, practical teaching becomes tokenism. The teachers also are influenced to focus on academic research and have unfortunate practical capacity and give perfunctory practice teaching.

3)Blind objectives of application-oriented technology talents training. Actual implementation in specific colleges and specialties has no teaching objectives that can reflect industry features and have practicability. In the process of practice teaching, practice for the sake of practice is common seen and massive students' internship in enterprises are just repeating inefficient work and they do not learn or do not efficiently learn the skills they should learn, resulting in waste of time.

\section{Analysis of influential factors of application-oriented technology talents training}

1) Application-oriented teaching staff. Application-oriented teaching staff is the basic guarantee for the application-oriented technology talents training. Only through application-oriented teachers and application-oriented curriculum system (theoretical and practical), supplemented by application-oriented teaching resources and application-oriented teaching method, can the training objectives be better obtained.

2) Path of practical teaching. Application-oriented technology talents training requires proper training models. Effective practical teaching enables students to consolidate theoretical knowledge, train professional skills, increase their employment competitive and employability.

3) Power of universities-enterprises cooperation. The power of universities-enterprises cooperation is the key to long-term performance of universities-enterprises cooperation. Enterprises' demands of talents and science and technology are an important driver for enterprises' participation in cooperative education. Only stimulating the motivation of universities-enterprises cooperation and enhancing the power of cooperation can contribute to the achievement of strategic alliances, complementary advantages, resources sharing and cultural integration.

4) Evaluation criteria. Application-oriented technical training evaluation criteria should present the following characteristics: first, the objectives should be based on application, specialty should be oriented by demands and the curriculum system should be based on capacities; with training objectives and the curriculum system, teachers should be double-qualification, the training should be made through collaborative education and the teaching process must emphasize on practical teaching.

\section{Construction of - universities-enterprises community of interests}

Based on the analysis of the above influencial factors, we found that universities-enterprises (school-governance, school-region and school-industry) cooperation is an effective way to application-oriented technology talents training. After years of exploration and practice, our university has formed six types of community of interests, including scientific research-contacted community of interests, internship-led community of interests, intermediary-bridged community of interests, policy-driven community of interests, expert-allied community of interests and order-cultured community of interests. The basic information is as follows.

1) Scientific research-contacted community of interests. Our university corporates with 
researchers, engineers and technicians in some research topics relying on the research teams to realize the systematical integration of the creation, processing, dissemination, and application of knowledge information.

2) Internship-led community of interests. Internship-led community of interests refers to having an agreement with enterprises about students' internship, providing internship opportunities for students, allowing students to go further the front production and management, understand the real operation situation or production process of enterprises, and improve their practical capacity, and enterprises choose the best applicants according to their performance during internship.

3) Intermediary-bridged community of interests. With the market economy reform and continuous improvement of the external environment of universities-enterprises cooperation, more intermediary agents will be involved in universities-enterprises cooperation. Intermediary agents can be divided into two categories: one is vocational training companies, the other is the industry associations which can represent industries and enterprises. Our university has established a close working relationship with some organizations through the mediation by some associations.

4) Government policy-driven community of interests. Government policy- driven community of interests, in which the government makes a full utilization of its functional advantages and encourages enterprises to participate in students training based on current economic and social development and through policy incentives and tax incentives. Our university carries out in-depth cooperation with Hangzhou Totyu, Insigma and other enterprises in training software service outsourcing talents [5][6].

5) Industrial expert-allied community of interests. Industrial expert-allied community of interests are the practice that a school invites the experienced and skilled industrial experts and senior leaders of enterprises to participate in school teaching, help students understand the employment environment and market needs, introduce advanced research fields and application fields.

6) Order-cultured community of interests. Order-cultured community of interests is a model of cooperation through which enterprises provide human resources of appropriate quantity and quality on schedule according to enterprises' requirements on number, level of knowledge and vocational skills through negotiation between enterprises and universities.

\section{Giving full play to leading roles of the community of interests in application-oriented technology talents training}

Universities-enterprises cooperation led by community of interests can fully enhance the initiatives of school and enterprise in cooperation and help to carry out all-round, in-depth and multiple forms of cooperation in specialty offering and connotation construction, personnel training mode reform, and college students' innovation capacity training, and students' practical capability, spirit of innovation and professional quality are improved significantly.

\section{Leading specialty setting and connotation construction}

(1) New specialties setting. To meet the diversified demands for talents in the economic society, we go to industrial enterprises for investigation, actively offers new specialties (fields), and invite senior experienced professionals from industrial enterprises to specialty offering steering committee based on market demand and through communication and discussion with cooperative enterprises. It offers specialties according to the "science-industry-occupation" logical relationship of knowledge application and through integration with industry, relying on industry and cooperation with enterprises.

(2) Talents training programs joint develoment. We invite enterprises to participate in talents training program establishment, discuss students' future positions and position capacity, analyze industry's requirement for knowledge, ability and quality of application-oriented talents. The specialties in our university are set and improved based on the market demands, their characteristics and actual teaching situation from the professional perspective. It clarifies professional fields and level of personnel training, and vigorously promotes the application-oriented improvement of curriculum and establishes an application-oriented curriculum system. 
(3) Deeply involved in the link of practice. The community of interests in universities-enterprises cooperation further deepens the universities-enterprises cooperation in strength and breadth. Different specialties have a number of stable bases. For the past two years, 49 new external student practice bases have been added. There have been 165 external practice bases, and the vast majority of specialties extend their practical training to enterprises. "Zhejiang Shuren University - Hangzhou Totyu Engineering Practical Educational Center", which is built jointly by our university and Hangzhou Totyu Technology Co., Ltd, was approved as a construction project of a state-level university students' off-campuspractice education base.

(4) Promoting the construction of double-qualification teachers. By attracting teachers armed with practical experience in the industry to work at our university and sending young teachers to enterprises for practice to construct "double-qualification" teaching staff. In addition, our university has implemented the "thousand industrial teacher scheme". Since it was launched in 2012, our university has employed more than 400 experienced and skilled experts to give collaborative instruction in classroom.

\section{Leading the personnel training mode reform}

(1) Initiating the pilot training of "excellent engineer scheme". Our university has launched the pilot reform of "excellent engineer scheme" in three specialties, such as civil engineering and so on, since 2012. For the pilot specialties, we visit relevant industries and enterprises and develop implementation programs for excellent engineer scheme by integrating with practice and promote specialty curriculum reform on a full scale. In the past three years, " $3+1$ " or " $2.5+0.5+0.5+0.5$ " training model has been launched as a pioneering engineering specialty reform in the pilot specialties thanks to the efforts made by the university and enterprises and resulted in in-depth participation of enterprises and made solid training of students' practical capacity. The employment rate of the first batch of students was nearly $100 \%$.

(2) Deepening the "order-cultured" universities-enterprises cooperation in personnel training. In recent years, the school jointly set up Red Rock Course with Zhejiang Red Rock Group for three times. The model of universities-enterprises "whole dual training assessment" for customized personnel training is introduced in this course. In universities-enterprises cooperation, they develop training programs and jointly design projectized courses, establish integrated universities-enterprises practical teaching, scientific research service and manage the innovation bases.

(3) Promoting the construction of universities-enterprises cooperation (virtual) courses. In nearly three years, we cooperated with some enterprises, in launching 35 courses, such as "Shuren • Juguang"and so on. Over 1300 students participated in universities-enterprises cooperation (virtual) courses. A new teaching and management system of "production-oriented internal practice and teaching-oriented external base" is initially formed.

\section{Leading the training of students' innovation, entrepreneurship and employment capacity}

(1) Improvement of vocational qualification certificate system. Since 2013, our university has amended training plans, established vocational qualification certificate system, and brought the certificates that are closely related to specialty and highly recognized in the society into training plans of different specialties, and gradually included related requirements into curriculum. All specialties have requirements on certificate.

(2) Boosting the reform of thethesis programs. According to the basic requirement of "set by enterprises, guided by double-qualification teachers, finished through cooperation and tested by market", we guide students to make design based more on the existing problems and the actual demand of industrial enterprises and to solve practical engineering problems and intensify our efforts to promote students to complete their graduation thesis (design) or other research projects in practical training and enhance their practical and innovative capacity.

(3) Carrying out students' innovation and entrepreneurship training actively. Our university attach great importance to students' innovation and entrepreneurship training and disciplinary competition, and invite talents from enterprises to guide project work. In 2010-2014, a total of 159 students' science and technology innovation and science and popularization projects of scientific 
and technological achievements of our school were established by Zhejiang Provincial College Student Science and Technology Innovation Project (Xinmiao Talent Program). In the past 4 years, our students won many prizes in Zhejiang "Challenge Cup" college students' extracurricular scientific and technological competition and entrepreneurship plan competition.

(4) Building integrated universities-enterprises business incubator. In recent years, our university relies on the specialty resources and greets 71 student pioneer studios in the business incubator and provides services for 879 students. 21 of 71 pioneer studios have incorporated in Hangzhou. Our university launched an "Entrepreneurship School" and trains students' entrepreneurship and forms entrepreneurial teams by means of business incubator service stations.

\section{Conclusion}

It is an important mission for application-oriented undergraduate construction to train application-oriented talents. Universities-enterprises cooperation is an important way for collaborative training of skilled talents that meet social needs and boosting regional economic and social transformation and development. Universities-enterprises cooperation can be used to effectively solve the problems in specialty setting, training objectives, training procedures and application-oriented teaching staff. In recent years, Zhejiang Shuren University steadily progresses in application-oriented reform, establishes and improves new universities-enterprises personnel training mechanisms. Graduates present a good employment situation, and the first employment rate remains above $95 \%$. Its graduates that have been highly recognized by society. This also proves the good results of the universities-enterprises community of interests in senior application-oriented technology talents training.

We believe that the universities-enterprises cooperation led by "interests community" will fully stimulate the initiative in universities-enterprises cooperation. With the all-round, in-depth and multiple forms of cooperation in specialty offering and connotation construction, personnel training mode reform, college students' innovation capacity training and other fields, the students' practical capability, spirit of innovation and professional quality are improved significantly, and the school will improve its ability to serve the society.

\section{References}

[1] Adinarayana Kalanidhi. Improving the collaboration between academic and industrial organisations in engineering and technology education. World Transactions on Engineering and Technology Education. Vol.12, No.4, 2014.P595-598.

[2] Xinmin Chen. An Analysis on Problems and Their Countermeasures of Inter-School Cooperation in New Undergraduate Universities[J]. China University Teaching. 2013,7, 18-20(2013).

[3] Hongtian Zhang. Exploring New Mechanisms for School-enterprise Cooperation \& Training High-Quality Skilled Technical Personnel [j]. China Higher Education, 2014,2. 31-33(2014).

[4] Xuqing Xu. Teaching Service-Oriented University: Theoretical Studies and Institutional Framework [m]. Chinese Social Science Press, 1-10(2014).

[5] Chaoxiang Chen etc. Training inter-disciplinary talent for software outsourcing. World Transactions on Engineering and Technology Education[J]. 13,2, 153-158(2015).

[6] Shiping Ye etc. Reform of Teaching and Practice for Outstanding ITO Engineers. World Transactions on Engineering and Technology Education[J]. 11,3,260-266(2013). 